\title{
KONTRIBUSI PENDAPATAN USAHATANI PADI GOGO TERHADAP PENDAPATAN RUMAHTANGGA DI DESA LELEKAA KECAMATAN WOLASI KABUPATEN KONAWE SELATAN
}

\author{
Farah Aulia Nur ${ }^{\left.{ }^{*}\right)}$, Sitti Aida Adha Taridala1), Fahria Nadiryati Sadimantara ${ }^{1)}$ \\ *Corresponding author : farahaulianur98@gmail.com
}

To cite this article:

Nur, F., Taridala, S., \& Sadimantara, F. (2021). Kontribusi Pendapatan Usahatani Padi Gogo terhadap Pendapatan Rumahtangga di Desa Lelekaa Kecamatan Wolasi Kabupaten Konawe Selatan. JIA (Jurnal IImiah Agribisnis) : Jurnal Agribisnis dan Ilmu Sosial Ekonomi Pertanian, 5(4), 150 - 158. doi:http://dx.doi.org/10.37149/jia.v5i4.13330

Received: August 06, 2020; Accepted: August 29, 2020; Published: August 31, 2020

\section{ABSTRACT}

This research is motivated by the fact that Gogo Rice cultivated by the majority of the community in Lelekaa Village, Wolasi District, South Konawe has the main objective as the main source of food needs in the family. In addition to fulfilling food, Gogo rice is also a farm product that can be managed to increase farm household income. The purpose of this study was to determine how much Gogo rice farm income and its contribution to household income in the Lelekaa village. The location of the study was determined with the consideration that the majority of the people in Lelekaa Village were still consistently planting Gogo rice. The number of samples in this study was 29 people. The data analysis used is descriptive quantitative. There are two research results. First, the average income of upland rice farming in Lelekaa Village, Wolasi Subdistrict, Konawe Selatan Regency is Rp 4.769.144/MT in one year. Second, the contribution of Gogo rice farming income to household income in Lelekaa Village, Wolasi District, Konawe Selatan Regency was 17,92\%. The contribution provided by other farms is smaller than Gogo rice farming with a percentage value of $9,28 \%$, while the contribution of non-agricultural income to household income holds the greatest value with a percentage of $72,80 \%$.

Keywords: contribution; farmers; gogo rice; households; income

\section{PENDAHULUAN}

Beras yang merupakan salah satu kebutuhan dan sumber makanan utama bagi mayoritas penduduk Indonesia yang permintaannya semakin meningkat, sedangkan kondisi lahan irigasi teknis sebagai wadah tumbuhnya padi sawah terus mengalami penururnan (degradasi) (Wahyunto \& Widiastuti, 2017). Salah satu upaya atau akternatif yang perlu dilakukan ialah melalui pengembangan usahatani di lahan kering secara optimal. (Idjudin \& Marwanto, 2008) menegaskan bahwa suatu cara yang dapat dilakukan untuk mendapatkan kesejahteraan bagi manusia melalui pengelolaan bagian lingkungan hidup yaitu dengan cara pengelolaan sumberdaya lahan kering. Dengan adanya pengembangan lahan kering maka pemanfaatan lahan semakin baik karena mengolah kembali lahan yang umumnya tidak digunakan untuk kegiatan pertanian dikarenakan keadaan tanah pada lahan kering yang menyebabkan sulitnya tanaman pangan untuk dibudidayakan.

Padi gogo atau padi ladang adalah alternatif tepat yang dapat dilakukan untuk mengatasi kebutuhan beras. Hal ini disebakan karena salah satu komoditas pangan yang dapat dibudidayakan pada daerah yang beriklim tropis dengan kondisi tanah yang kering yaitu padi ladang atau padi gogo. Sejalan dengan penelitian (Fitria \& Ali, 2014) menjelaskan bahwa sumber daya lahan yang dapat digunakan untuk eskalasi pengembangan padi melalui budi daya padi gogo yaitu dengan menggunakan lahan kering. Hal ini dikarenakan padi gogo adalah komoditas yang biasanya ditanam secara tunggal pada lahan terbuka/ladang, tumpangsari dengan tanaman pangan lainnya ataupun pada daerah aliran sungai (DAS).

Konawe Selatan mengambil peran sebagai daerah penghasil beras di Sulawesi Tenggara. Salah satu kecamatan yang masyarakatnya banyak menanam padi yaitu Kecamatan Wolasi. Kecamatan Wolasi sendiri memiliki jumlah luas tanam dan luas panen yang cukup luas, namun untuk 
tahun 2015-2017 luas lahan tanaman padi mulai berkurang. Menurut BPS Konawe Selatan (2018) menjelaskan dari tahun 2015 hingga 2017 luas tanam maupun luas panen, baik itu tanaman padi sawah maupun padi ladang di Kecamatan Wolasi semakin mengecil. Luas tanam dan luas panen tanaman padi sawah pada tahun 2015-2016 memiliki persentasi yang perubahan $0 \%$ yang artinya tidak mengalami penambahan luas lahan. Perubahan yang cukup besar terjadi ditahun selanjutnya yakni 2017, baik itu luas tanam maupun luas panen padi sawah menurun hingga mencapai angka $23 \%$. Begitu pula pada padi gogo, jenis tanaman padi gogo untuk luas tanam dan luas panen juga mengalami pengurangan luas lahan namun tidak sebanyak luas tanam dan luas panen padi sawah (BPS, 2018).

Desa Lelekaa adalah salah satu daerah yang berada di kawasan Kecamatan Wolasi Kabupaten Konawe Selatan yang juga mengambil peran sebagai salah satu daerah penyumbang produksi padi gogo. (Rahayu, Taufik, Tupaila, \& Hasid, 2019) menjelaskan bahwa sumber karbohidrat utama bagi masyarakat di Kecamatan Wolasi pada umumnya adalah padi gogo. Begitu juga dengan Desa Lelekaa. Sebagian besar masyarakat Desa Lelekaa membudidayakan padi gogo diperuntukkan untuk konsumsi dan benih untuk masa tanam selanjutnya. Hasil produksi akan dijual apabila ada konsumen yang memesan hasil panen yang umumnya juga masih kerabat dekat ataupun kenalan dan tidak dijual secara kontinyu. Selain untuk konsumsi petani, padi gogo juga dapat menjadi sumber penghasilan tambahan rumahtangga.

Kontribusi pendapatan dapat menjadi informasi bagi petani untuk mengetahui seberapa besar sumbangan pendapatan usahatani padi gogo terhadap pendapatan rumahtangga, dimana anggota keluarga juga dapat melakukan pekerjaan di luar usahatani padi gogo tersebut (Hariati, Limi, \& Fyka, 2018). Sumber-sumber pendapatan usahatani padi gogo merupakan hal yang menarik untuk diteliti terutama berapa besar kontribusinya terhadap pendapatan rumahtangga guna membiayai kebutuhan hidup sehari-hari dan juga untuk kesejahterahan para petani dan keluarga. Fenomena yang saat ini jarang ditemui yang menjadi tujuan utama proses produksi petani padi gogo adalah untuk memenuhi kebutuhan pangan keluarganya (S. Taridala et al., 2018). Usahatani padi gogo yang diusahakan oleh petani di Desa Lelekaa selama ini hanya dimanfaatkan sebagian besar untuk kebutuhan keluarga sebagai bahan pangan pokok, belum dijual kemudian dijadikan sebagai sumber pemenuhan kebutuhan utama bagi petani. Oleh karena itu perlu adanya riset mendalam mengenai berapa pendapatan usahatani padi gogo tersebut kemudian seberapa besar kontribusinya terhadap pendapatan rumahtangga. Tujuan dilakuannya penelitian ini yaitu untuk mengetahui besaran pendapatan yang diperoleh para petani padi gogo di Desa Leleka dan kontribusinya bagi pendapatan rumahtangga petani.

\section{MATERI DAN METODE}

Penelitian ini dilaksanakan di Desa Lelekaa Kecamatan Wolasi Kabupaten Konawe Provinsi Sulawesi Tenggara. Penentuan lokasi penelitian dilakukan secara sengaja (purposive) pada unit desa yang sesuai dengan tujuan penelitian. Pemilihan wilayah tersebut dengan dasar pertimbangan bahwa Lelekaa merupakan desa di Kecamatan Wolasi yang masyarakatnya paling banyak membudidayakan padi ladang (padi gogo) menurut laporan (S. A. A. Taridala, Abdullah, \& Wianti, 2016). Pengambilan data telah dilaksanakan pada bulan Februari Sampai Oktober 2019 dan penulis melakukan pengambilan data pada bulan Februari sampai Maret 2020 untuk melengkapi data yang telah ada. Jumlah sampel yang diambil sebanyak $20 \%$ dari keseluruhan jumlah populasi yaitu 29 orang (Arikunto, 2006). Analisis data pada penelitian ini yaitu kuantitatif deskriptif dengan menggunakan rumus pendapatan $(\mathrm{Pd}=\mathrm{TR}-\mathrm{TC})$, pendapatan rumahtangga $\left(\mathrm{Pd} \mathrm{RT}=\sum \mathrm{Pd}\right)$ dan kontribusi pendapatan (K =Pd Ut/Pd RT x 100\%)

\section{HASIL DAN PEMBAHASAN}

\section{Karakteristik Responden}

Karakteristik responden yang terdapat pada penelitian ini meliputi variabel-variabel yang berhubungan langsung dengan petani juga usahatani yang dijalankan yaitu padi gogo, yang terdiri dari umur, pendidikan, luas lahan yang digarap dan jumlah anggota keluarga. Hal ini didasarkan pada hasil penelitian oleh (Mathieu \& Zajac, 1990) yang menjelaskan bahwa usia, jenis kelamin, masa kerja, tingkat pendidikan, suku bangsa, dan kepribadian merupakan karakteristik yang dimiliki oleh suatu individu. Karakteristik yang merupakan identitas petani inilah yang nantinya akan mempengaruhi petani dalam pengambilan keputusan mengenai kegiatan usahataninya. 
Tabel 1. Karakteristik responden

\begin{tabular}{|c|c|c|c|}
\hline No & Karakteristik & Jumlah Petani & Persentase \\
\hline \multicolumn{4}{|c|}{ 1. Umur } \\
\hline & $0-14$ & 0 & 0 \\
\hline & $15-64$ & 21 & 72,4 \\
\hline & $\geq 65$ & 8 & 27,6 \\
\hline \multicolumn{4}{|c|}{ 2. $\quad$ Pendidikan } \\
\hline & Tidak sekolah/Tidak Tamat SD & 3 & 10,4 \\
\hline & SD & 21 & 72,4 \\
\hline & SMP & 3 & 10,4 \\
\hline & SMA & 1 & 3,4 \\
\hline & Sarjana & 1 & 3,4 \\
\hline \multicolumn{4}{|c|}{ Jumlah Anggota Keluarga } \\
\hline & $\leq 2$ & 11 & 37,9 \\
\hline & $3-4$ & 11 & 37,9 \\
\hline & $\geq 5$ & 7 & 24,2 \\
\hline \multirow[t]{4}{*}{4} & Luas Lahan & & \\
\hline & $<0,5$ & 0 & 0 \\
\hline & $0,5-2$ & 25 & 86,2 \\
\hline & $>2$ & 4 & 13,8 \\
\hline
\end{tabular}

Sumber : Data primer 2019

Hasil pengumpulan data dilapangan menunjukkan bahwa usia responden terbesar berada pada umur produktif yaitu $72 \%$ atau sebanyak 21 orang dari 29 orang. Berdasarkan komposisi penduduk, usia penduduk dibagi atas tiga golongan. Golongan pertama yaitu 0-14 tahun yang dinamakan usia muda atau belum produktif, golongan kedua usia 15-64 tahun yang dinamakan usia matang atau produktif, terakhir golongan ketiga yaitu $\geq 65$ tahun merupakan usia tua/ tidak produktif (Mulyadi, 2014). Golongan belum produktif tidak ada dan tidak produktif sebesar $27 \%$. Hal ini menunjukkan bahwa rata-rata petani padi gogo di Desa Lelekaa berada pada usia produktif menuju usia tidak produktif. Artinya, petani padi gogo seharusnya sudah tidak lagi bekerja dengan umur yang sudah lanjut usia, dimana kemampuan fisik dalam bekerja sudah mulai berkurang. Namun, kenyataan dilapangan menjelaskan bahwa para petani padi gogo ini masih sanggup dalam menjalankan usahataninya. Sesuai dengan pendapat (Fifin, 2018) umumnya, orang yang memiliki usia lebih muda dan juga sehat jasmani mempunyai fisik yang lebih kuat dengan kreatifitas pola pikir yang baik juga lebih peka terhadap teknologi ataupun kemajuan informasi sehingga dalam mengeola usahataninya, mereka akan lebih dinamis dan cenderung adaptif dengan teknologi. Sebaliknya, yang lebih tua dalam mengelola usahatani akan lebih memiliki banyak pertimbangan mengenai adopsi teknologi serta kegiatan lainnya.

Pendidikan pada penelitian ini adalah tingkat pendidikan formal terakhir yang pernah dijalani oleh responden yaitu petani padi gogo. Fungsi dari pendidikan sendiri menurut (Mulyadi, 2014) iyalah menyiapkan sumber daya manusia yang lebih berkualitas agar dapat lebih produktif dalam bekerja. Tingkat pendidikan para responden petani padi gogo di Desa Lelekaa kecamatan Wolasi Kabupaten Konawe Selatan sebagian besar berpendidikan Sekolah Dasar (SD) dengan persentase $72,4 \%$ atau sebanyak 21 orang dari total keseluruhan reponden. Responden yang berpendidikan Sekolah Menengah Pertama (SMP) memiliki persentase 10,4\%. Hal ini menjelaskan bahwa sebagian besar petani memiliki pendidikan formal yang rendah. Ditambah 3 orang reponden yang tidak mengenyam pendidikan sama sekali. Oleh karena itu, dalam menjalankan usahatani padi gogo petani banyak menggunakan pengalaman berusahatani yang telah turun temurun sejak dahulu.

Jumlah anggota keluarga petani responden petani di Desa Lelekaa berkisar 0-7 orang, dengan responden yang memiliki anggota keluarga paling banyak dengan kisaran lebih dari atau sama dengan lima anggota keluarga berada pada $24,2 \%$ atau berjumlah 7 orang responden. Selebihnya untuk jumlah responden yang memiliki anggota keluarga dibawah lima orang terdiri dari dua bagian, responden yang memiliki anggota keluarga dua orang atau kurang yaitu 11 orang dengan persentase $37,9 \%$ dan responden yang memiliki anggota keluarga tiga sampai empat orang berada pada $37,9 \%$ atau berjumlah 11 responden. Jumlah anggota keluarga dapat menjadi sumber tenaga kerja untuk membantu dalam pengelolaan kegiatan usahatani, yang kemudian dapat menambah pendapatan keluarga. Oleh karena itu, banyaknya anggota keluarga dalam suatu rumah tangga menggambarkan ketersediaan tenaga kerja (Fadholi Hernanto, 1989). Petani responden ratarata memiliki anggota keluarga yang berumur produktif, yang dapat menjadi tambahan tenaga kerja. (S. Taridala et al., 2018) menyatakan bahwa jika tanggungan keluarga masuk dalam umur produktif, 
maka dapat digunakan sebagai sumber tenaga kerja keluarga dan dapat memberikan keuntungan bagi petani non produktif untuk membantu kegiatan usahataninya.

Sebagian besar luas lahan milik petani padi gogo di Desa Lelekaa adalah luas lahan garapan sedang dengan persentase $86,2 \%$ atau sebesar 25 orang. Untuk petani yang memiliki luas lahan garapan luas yaitu berjumlah 7 orang dengan persentase 13,8\%. Keadaan ini menjelaskan bahwa kebanyakan petani padi gogo di Desa Lelekaa adalah petani lahan sedang. Sejalan dengan (Soekartawi, 2002) yang menjelaskan bahwa di Indonesia peneliti sering menggunakan kategorisasi petani berdasarkan luas lahan yang diusahakan, yang terdiri dari : luas lahan garapan sempit $(<0,5$ $\mathrm{Ha})$, luas lahan garapan sedang $(0,5-2 \mathrm{Ha})$, dan luas lahan garapan luas $(>2 \mathrm{Ha})$. (Hartono, Rosni, \& Salawati, 2020) menyatakan bahwa pendapatan rumah tangga pemilik usahatani padi gogo dapat dipengaruhi oleh besaran luas lahan. Artinya, semakin besar lahan garapan petani maka kesempatan untuk mendapatkan hasil produktivitas lebih semakin besar.

\section{Biaya Tetap dan Biaya Variabel Usahatani Padi Gogo}

Biaya tetap adalah korbanan yang besarannya tidak dipengaruhi oleh jumlah produksi yang dihasilkan (Tuwo, 2011). Artinya, biaya ini besarannya tidak tergantung pada berapapun hasil produksi usahatani tersebut. Biaya tetap pada usahatani padi gogo di Desa Lelekaa merupakan biaya penyusutan peralatan dalam usahatani yang dijalankan. Lebih lanjut Menurut (Tuwo, 2011) biaya variabel adalah korbanan yang terdiri dari jumlah biaya-biaya yang diperhitungkan dalam jangka waktu tertentu. Artinya, jumlah biaya variabel tergantung dari banyaknya produksi yang dihasilkan pada jangka waktu tertentu. Jumlah biaya tetap dan biaya variabel rata-rata yang dikorbankan oleh petani padi gogo pada usahataninya untuk satu musim tanam dalam setahun dapat dilihat pada Tabel 2.

Tabel 2. Biaya Tetap dan biaya variabel rata-rata usahatani padi gogo/musim tanam di Desa Lelekaa Kecamatan Wolasi Kabupaten Konawe Selatan Tahun 2019

\begin{tabular}{clr}
\hline No & \multicolumn{1}{c}{ Komponen Biaya } & Jumlah (Rp/Usahatani) \\
\hline 1 & Biaya Tetap & \\
& Biaya penyusutan peralatan & 69.049 \\
& a. Parang & 32.389 \\
& b. Kampak & 4.734 \\
& c. Ani-Ani & 30.519 \\
& d. Keranjang & 13.435 \\
e. Sabit & 55.455 \\
& f. Hand Sprayer & 15.894 \\
\hline & g. Cangkul Jumlah Biaya tetap & 117.696 \\
\hline \multicolumn{2}{l}{ Biaya Variabel } \\
& Tenaga kerja Luar Keluarga \\
& a. Persiapan lahan & 1.478 .448 \\
& b. Penanaman & 327.586 \\
& c. Pembuatan pagar & 553.448 \\
d. Perawatan tanaman & 224.828 \\
e. Panen & 1.742 .069 \\
\hline
\end{tabular}

Sumber : Data primer 2019

Keseluruhan biaya tetap rata-rata pada Tabel 2 sebesar Rp117.696 merupakan penjumlahan dari biaya penyusutan keseluruhan peralatan usahatani padi gogo. Penyusutan alat yang digunakan dalam proses produksi dihitung dengan cara mengurangkan nilai beli dengan nilai sisa kemudian dibagi umur ekonomis alat.Hasil perhitungan kemudian dikonversikan ke dalam satu kali musim tanam. Nilai sisa adalah perkiraan nilai suatu alat disaat waktu alat tersebut sudah habis atau tidak dapat dipegunakan lagi dan dianggap nol (Suratiyah, 2015).

Rata-rata pada usahatani padi sawah, pajak lahan termasuk biaya tetap. Diantaranya penelitian yang dilakukan oleh (Maluhima, Memah, \& Sendow, 2020) dengan biaya pajak lahan Rp25.318,811 dan juga (Anton \& Marhawati, 2016) sebanyak Rp10.488,88. Namun, berdasarkan hasil temuan penelitian ini, pajak lahan tidak masuk dalam biaya tetap karena tidak seorang pun petani padi gogo di desa Lelekaa yang membayar pajak lahan. Karena tanah yang diolah merupakan lahan berada di kawasan yang berbatasan dengan hutan dan belum memiliki surat tanda kepemilikan 
lahan. Serupa dengan temuan) (Hariati et al., 2018) dimana biaya tetap dalam penelitian ini tidak ada pajak lahan dalam biaya usahatani padi gogo.

Pada Tabel 2 menggambarkan bahwa biaya variabel rata-rata yang dikorbankan oleh petani padi gogo sebesar Rp4.422.241, yang merupakan keseluruhan jumlah biaya tenaga kerja luar keluarga. Maksudnya, tenaga kerja dari luar anggota keluarga inti, namun masih merupakan kerabat dekat. Dalam penelitian ini, biaya variabel hanya merupakan biaya tenaga kerja, tidak ada biaya pupuk atau benih. Sejalan dengan penelitian (Erna, Taridala, \& Indarsyih, 2018) biaya variabel pada penelitian ini yaitu pestisida dan biaya tenaga kerja keluarga. Para petani padi gogo di Desa Lelekaa tidak menambahkan unsur hara tambahan, baik pupuk organik maupun anorganik. Demikian juga dengan benih, petani telah menyisihkan benih dari hasil panen sebelumnya untuk musim tanam selanjutnya.

Hasil temuan ini menjelaskan bahwa kegiatan panen membutuhkan korbanan tertinggi dalam komponen biaya variabel. Biaya ini mengambil bagian sebanyak $40 \%$ dari keseluruhan biaya variabel. Biaya yang dikeluarkan tidak dalam bentuk uang melainkan lama bentuk upah natura. Sependapat dengan penelitian yang dilakukan oleh (Iriyanto, Widayati, \& Taridala, 2019) menerangkan bahwa sistem pemberian upah bagi tenaga kerja yang ikut membantu dalam kegiatan panen adalah sistem bagi hasil. Tingginya korbanan biaya panen disebabkan kegiatan ini umumnya dilakukan oleh tenaga panen yang tidak dibatasi baik jumlahnya, yang berarti banyak tenaga yang bisa membantu kegiatan panen. Selain itu, sistem pembagian hasil pada kegiatan panen juga menambah biaya yang harus dikorbankan, dikarenakan mayoritas pembagian hasil panen padi gogo yaitu 3:2 ikat. Jika diperoleh 5 ikat, maka 3 ikat padi untuk pemilik lahan dan 2 ikat untuk pemanen. Bahkan, apabila ada janda turut membantu mereka diberi sesuai dengan yang telah mereka panen sendiri.

\section{Penerimaan Usahatani Padi Gogo}

Hasil perkalian antara harga dan jumlah produksi yang dihasilkan merupakan nilai dari Penerimaan (Soekartawi, 2016). Penerimaan pada usahatani padi gogo adalah jumlah panen (setelah dikurangi benih untuk musim tanam selanjutnya) yang dihasilkan dalam satu kali musim tanam pertahun lalu dikalikan dengan harga pasar, atau harga jual padi gogo yang diterapkan petani apabila menjual hasil produksinya. Hasil produksi awal yaitu berupa padi dalam bentuk ikatan. Satu ikat padi sama dengan dua belas liter gabah atau sepuluh kilogram gabah, kemudian setelah digiling atau di tumbuk menjadi sepuluh liter beras atau delapan kilogram beras bersihnya. Informasi mengenai penerimaan usahatani padi gogo dapat dilihat pada Tabel 3.

Tabel 3. Penerimaan dan pendapatan rata-rata usahatani padi gogo/musim tanam di Desa Lelekaa Kecamatan Wolasi Kabupaten Konawe Selatan tahun 2019

\begin{tabular}{clr}
\hline No & \multicolumn{1}{c}{ Keterangan } & Jumlah \\
\hline 1. & Total produksi (Kg/Usahatani) & 465,54 \\
2. & Luas Lahan (Ha/Usahatani) & 1,39 \\
3. & Harga (Rp/Kg) & 20.000 \\
4. & Penerimaan (Rp/MT) & 9.233 .218 \\
2. & Biaya Total Rata-Rata & 4.464 .075 \\
3. & Pendapatan Rata-Rata & 4.769 .144 \\
\hline
\end{tabular}

Sumber : Data primer 2019

Data pada Tabel 3 menunjukkan bahwa penerimaan rata-rata yang didapatkan oleh petani berjumlah Rp9.233.218/satu kali musim tanam dalam jangka waktu satu tahun. Hasil temuan menjelaskan bahwa jumlah penerimaan yang diperoleh pada usahatani padi sawah umumnya lebih tinggi dibanding dengan usahatani padi gogo. Dibuktikan dengan temuan (Erna et al., 2018) yang mendapatkan nilai penerimaan usahatani padi gogo mencapai Rp9.233.218 dan penerimaan usahatani padi sawah mencapai Rp.13.573.405 pertahun 2018. Nilai penerimaan usahatani padi gogo didapat dari hasil perkalian antara total produksi dalam bentuk kilogram dan harga adalah harga yang dipakai oleh petani untuk menjual hasil produksi apabila ada yang meminta atau memesan secara pribadi ke petani. Produksi umumnya dalam bentuk ikatan padi yang kemudian di konversikan menjadi beras. Hasil penelitian menunjukkan bahwa 1 ikat padi hasil panen menghasilkan 5 liter beras dan apabila dikonversikan ke bentuk kilogram menjadi $4 \mathrm{~kg}$ untuk ikatan kecil dan 10 liter beras untuk ikatan besar menjadi $8 \mathrm{~kg}$. Harga jual padi gogo yang digunakan yaitu Rp15.000 per liternya, setelah dikonversikan ke kilogram menjadi Rp20.000 per kilogram.

Hasil dari mengurangi nilai penerimaan yang didapatkan oleh petani dengan biaya produksi yang dikorbankan dalam usahataninya adalah pendapatan usahatani padi gogo. Tabel 3. 
menunjukkan bahwa pendapatan rata-rata usahatani padi gogo sebesar Rp4.769.144/MT dengan penerimaan rata-rata Rp9.233.218 dan biaya total rata-rata sebesar Rp4.464.075MT. Hasil temuan (Erna et al., 2018) didapatkan bahwa pendapatan rata-rata usahatani padi gogo di Kabupaten Konawe Selatan tergolong rendah dibanding dengan pendapatan usahatani padi sawah, dengan hasil membuktikan bahwa pendapatan usahatani padi sawah nyaris dua kali lebih banyak dari padi gogo. Hasil temuan yang didapatkan yaitu pendapatan usahatani padi gogo di Desa Lelekaa sangat sedikit dibandingkan dengan usahatani padi gogo di daerah lain. Salah satu temuan oleh (Hartono et al., 2020) menyatakan bahwa pendapatan padi gogo di Desa Perbakulan perusahatani mencapai Rp16.934.850 pertahunnya. Besar dan kecilnya pendapatan usahatani dipengaruhi oleh sebeapa besar penerimaan dan biaya usahataninya, menurut pendapat (Soekartawi, 2016) melalui rumus pendapatan usahatani yaitu selisih antara penerimaan usahatani dengan biaya produksi usahatani.

Minimnya pendapatan usahatani padi gogo di Desa Lelekaa umumnya dikarenakan petani tidak terlalu mementingkan antara penerimaan, biaya maupun pendapatan yang mereka terima. Alasannya karena pada dasarnya hasil produksi yang mereka dapatkan itu tidak untuk diperjualbelikan, melainkan hanya untuk sebagai konsumsi sehari-hari untuk melangsungkan kehidupan (S. Taridala et al., 2018). Sedangkan untuk daerah-daerah yang sudah mengembangkan padi gogo secara komersil dan mempertimbangkan penerimaan serta biaya menyebabkan pendapatan yang diterima akan lebih besar (Fitria \& Ali, 2014).

\section{Pendapatan Usahatani Lain}

Pendapatan usahatani lain merupakan hasil dari pendapatan dari berbagai sumber penghasilan petani selain dari usahatani padi gogo selama satu tahun. Usahatani lain yang di lakukan oleh petani responden dalam penelitian ini antara lain adalah ternak ayam dan usahatani sagu. Informasi mengenai distribusi pendapatan usahatani lain dapat dilihat pada Tabel 4.

Tabel 4. Pendapatan rata-rata usahatani lain di Desa Lelekaa Kecamatan Wolasi Kabupaten Konawe Selatan Tahun 2019

\begin{tabular}{cccccc}
\hline No & Jenis Usahatani & $\begin{array}{c}\text { Jumlah } \\
\text { (jiwa) }\end{array}$ & $\begin{array}{c}\text { Penerimaan } \\
\text { rata-rata } \\
\text { (Rp/Tahun) }\end{array}$ & $\begin{array}{c}\text { Biaya } \\
\text { rata-rata } \\
\text { (Rp/Tahun) }\end{array}$ & $\begin{array}{c}\text { Pendapatan } \\
\text { Rata-rata } \\
\text { (Rp/Tahun) }\end{array}$ \\
\hline 1. & Ternak Ayam & 12 & 658.333 & 98.750 & 559.583 \\
2. & Usahatani sagu & 2 & 13.750 .000 & 2.300 .000 & 11.450 .000 \\
\hline \multicolumn{2}{r}{ Jumlah } & 14 & \multicolumn{2}{c}{ Rata-rata } & 2.467 .917 \\
\hline
\end{tabular}

Sumber : Data primer 2019

Berdasarkan hasil temuan peneliti, diperoleh bahwa untuk menambah jumlah penghasilan rumahtangga, responden juga melakukan usahatani lain yang dilakukan selain usahatani padi gogo. Usaha tersebut iyalah ternak ayam yang dilakukan oleh responden sampingan sebanyak 12 orang dan juga usahatani sagu sebanyak 2 orang. Maka dari itu, pendapatan yang akan dihitung diambil dari dua usaha tersebut. Sejalan dengan penelitian (Nurmala \& Asse, 2020) yang menghitung pendapatan usahatani lain dengan memperhitungkan beberapa sumber diluar dari usahatani cengkeh sebagai objek utama penelitian.

Tabel 4 menunjukan bahwa pendapatan rata-rata dari usaha ternak ayam dihitung berdasarkan penerimaan rata-rata dikurangi biaya rata-rata, yaitu sebesar Rp559.583. Minimnya pendapatan ternak ayam dikarenakan usaha ternak ini hanya dilakukan sebagai kegiatan sambilan petani dengan memelihara ayam disekitar rumah. Olehnya itu, jumlah ternak yang dimiliki relatif sedikit dan biaya yang dikorbankan untuk pakan juga minim. Kemudian untuk pendapatan rata-rata usahatani sagu dikalkulasikan dengan cara yang sama mendapatkan hasil sebesar Rp11.450.000. Dengan demikian, total pendapatan usahatani lain setelah dirata-ratakan adalah Rp2.467.917. Jumlah yang dihasilkan oleh usahatani lain lebih sedikit dibanding dengan usahatani padi gogo. Sejalan dengan penelitian (Maluhima et al., 2020) yang mendapatkan jumlah pendapatan usahatani lain hanya sebesar Rp1.249.500, lebih sedikit dengan usahatani padi sawah sebagai objek utama penelitian.

\section{Pendapatan Non Pertanian}

Pendapatan non pertanian (usahatani) adalah pendapatan yang sumber penghasilannya berasal diluar bidang pertanian. (Manginsela \& Wangke, 2019) menyatakan bahwa pendapatan yang diperoleh responden selain berusaha sebagai petani yaitu sebagai buruh dan lain-lain yang diluar pertanian adalah pendapatan non-pertanian. Jenis sumber penghasilan yang dimiliki oleh petani responden di Desa Lelekaa terdiri dari sembilan bagian. 
Tabel 5. Pendapatan rata-rata non pertanian di Desa Lelekaa Kecamatan Wolasi Kabupaten Konawe Selatan Tahun 2019

\begin{tabular}{clcc}
\hline No & \multicolumn{1}{c}{ Uraian } & Jumlah (jiwa) & Jumlah (Rp/Tahun) \\
\hline 1. & PNS & 1 & 44.400 .000 \\
2. & Tukang Kayu & 3 & 24.000 .000 \\
3. & Pengrajin Rotan & 1 & 24.000 .000 \\
4. & Dagang Sembako & 2 & 45.000 .000 \\
5. & Penebang Kayu & 1 & 12.000 .000 \\
6. & Buruh bangunan & 1 & 18.000 .000 \\
\hline 7. & Satpam & 1 & 18.000 .000 \\
8. & Buruh tani & 1 & 5.120 .000 \\
9. & Kiriman & 5 & 5.280 .000 \\
\hline \multicolumn{2}{c}{ Pendapatan Rata-Rata } \\
\hline
\end{tabular}

Sumber : Data primer, 2019

Sumber penghasilan non usahatani berdasarkan hasil temuan berasal dari berbagai macam jenis pekerjaan yang dilakukan, hingga mendapat transfer uang dari anak yang sudah bekerja di luar daerah. Macam-macam jenis pekerjaan yang dilakoni ialah terdiri dari PNS (Pegawai Negeri Sipil), Tukang Kayu, Pengrajin Rotan, Dagang Sembako, Penebang Kayu, Buruh Bangunan, Satpam, dan Buruh Tani, sedangkan yang bukan pekerjaan yaitu bersumber dari Kiriman. Serupa dengan penelitian (Syamsiyah, Thoriq, Pardian, Karyani, \& Kusno, 2017) bahwa pendapatan non pertanian berasal dari sektor lain diluar usahatani yang diusahakan.

Tabel 5 menjelaskan bahwa total pendapatan rata-rata non pertanian berkisar Rp19.370.000 perusahatani pertahun, dengan penyumbang nilai terbesar bersumber dari Pegawai Negeri Sipil dengan rata-rata Rp44.400.000/Tahun dan Dagang Sembako dengan rata-rata Rp45.000.000/Tahun. Sumber penghasilan yang berasal dari kiriman memiliki gab atau perbedaaan besar dengan sumber yang lain, dengan nilai Rp5.280.000. Sumber penghasilan yang berasal dari kiriman ini berada pada responden yang umurnya memang sudah menginjak lanjut usia, antara 55-72 tahun. Petani ini menerima kiriman uang dari anak yang sudah bekerja sendiri diluar rumah dimana responden ini sudah tidak mampu lagi untuk mencari pekerjaan tambahan guna meningkatkan pendapatan rumah tangga. Serupa dengan penelitian (Syamsiyah et al., 2017) akibat faktor usia yang semakin tua, beberapa petani yang tidak memiliki tambahan penghasilan.

\section{Analisis Kontribusi Pendapatan Usahatani Padi Gogo terhadap Pendapatan Rumahtangga}

Menurut (Bhastoni \& Yuliati, 2016) di daerah pedesaan umunya memiliki sumber pendapatan bukan hanya satu sumber saja, namun dari berbagai sumber yang berasal dari sektor dalam maupun dari luar pertanian. Total pendapatan rumahtangga petani padi gogo di Desa Lelekaa merupakan hasil seluruh pendapatan bersih dari pendapatan usahatani padi gogo, pendapatan dari luar usahatani padi gogo, dan non pertanian yang dihitung dengan rumus pendapatan rumahtangga. Ketiga pendapatan ini kemudian akan dianalisis kontribusinya masing-masing terhadap total keseluruhan pendapatan rumahtangga, dengan tujuan untuk mengetahui seberapa banyak kontribusi dari pendapatan usahatani padi gogo terhadap total pendapatan dalam satu rumahtangga. Menurut (Hariati et al., 2018) tujuan analisis kontribusi dalam penelitian yaitu agar memberikan pertimbangan bagi pelaku usaha untuk memilih tetap berusahatani padi gogo atau beralih pekerjaan yang lebih besar sumbangannya terhadap pendapatan keluarga. Informasi tentang pendapatan rata-rata usaha dan kontribusinya dapat dilihat pada Tabel 6 .

Tabel 6. Jenis pendapatan rata-rata usaha dan kontribusinya terhadap pendapatan rumahtangga di Desa Lelekaa Kecamatan Wolasi Kabupaten Konawe Selatan Tahun 2019

\begin{tabular}{cccc}
\hline \multirow{2}{*}{ No } & Jenis Usaha & Pendapatan rata-rata & Kontribusi \\
& $(\mathrm{Rp})$ & $(\%)$ \\
\hline 1. & Usahatani Padi Gogo & 4.769 .144 & 17,92 \\
2. & Usahatani lain & 2.467 .917 & 9,28 \\
3. & Usaha non Pertanian & 19.370 .000 & 72,80 \\
\hline & Pendapatan Rumahtangga & 26.608 .843 & 100 \\
\hline
\end{tabular}

Sumber : Data primer, 2019 
Tabel 6 menunjukkan bahwa rata-rata besar pendapatan usahatani padi gogo yaitu Rp4.769.144/MT/Tahun dengan kontribusi persentasenya sebesar $17,92 \%$ terhadap pendapatan rumahtangga petani responden. Nominal pendapatan usahatani padi gogo di Desa Lelekaa tergolong sangat rendah, dikarenakan hasil produksi yang didapatkan lebih kecil dibanding dengan produktivitas pertanian padi gogo yang dapat mencapai 2,4-3 Ton/Ha dalam satu kali musim tanam (S. Taridala et al., 2018). Hasil temuan menunjukan bahwa sumber pendapatan yang memiliki kontribusi terbesar adalah usaha non pertanian, dengan nilai kontribusi sebesar $72,80 \%$. Hal ini menunjukkan bahwa petani padi gogo di Desa Lelekaa pada dasarnya tidak menjadikan usahatani padi gogo sebagai sumber pendapatan utama. Kontribusi pendapatan usaha non pertanian terhadap pendapatan rumahtangga mencapai Rp19.370.000, memiliki selisih Rp14.600.856 dengan usahatani padi gogo. Serupa dengan penelitian yang dilakukan oleh (Hariati et al., 2018) bahwa besar kontribusi usahatani padi gogo lebih sedikit dibanding dengan usaha diluar usahatani padi gogo.

Fakta pada penelitian mengenai rendahnya pendapatan padi gogo yang diterima oleh petani menyebabkan mereka memiliki beberapa profesi tambahan untuk mencukupi kebutuhan rumahtangga. Karena pada dasarnya, petani di Desa Lelekaa mengusahakan tanaman padi gogo ialah untuk memenuhi kebutuhan kebutuhan pangan keluarga, bukan untuk tujuan komersial (S. Taridala et al., 2018). Lanjut (S. Taridala et al., 2018) juga menyatakan bahwa "Jika para petani hanya mengandalkan pendapatan pendapatan dari bekerja di pertanian padi gogo tanpa meningkatkan teknologi budidaya maka rumahtangga petani padi gogo dapat tergolong miskin". Jelas bahwasannya salah satu faktor utama yang menyebabkan pendapatan usahatani padi gogo yang diperoleh sangat kecil, yaitu akibat teknologi budidaya yang digunakan kurang baik dan tepat. Hal menarik yang dipercayai oleh petani padi gogo yaitu dengan tidak memberantas hama tikus melainkan hanya diusir dari lahan tanpa dibunuh atau diberi racun. Untuk pengendalian hama yang berupa tikus, tidak ada perlakuan khusus yang dilakukan oleh petani (seperti penggunaan bahan kimia berupa racun tikus), namun hanya dibiarkan dan dikontrol dengan harapan serangan hama tikus tidak akan meluas dengan cara menjaga sikap agar tidak berkata 'sembarang' yang dapat mengundang tikus yang lebih banyak (Iriyanto et al., 2019).

\section{KESIMPULAN DAN SARAN}

Berdasarkan hasil penelitian dan pembahasan, maka dapat disimpulkan bahwa pendapatan rata-rata usahatani padi gogo di Desa Lelekaa Kecamatan Wolasi Kabupaten Konawe Selatan sebesar Rp4.769.144/MT/UT dalam kurun waktu satu tahun. Kontribusi pendapatan usahatani padi gogo terhadap pendapatan rumahtangga di Desa Lelekaa Kecamatan Wolasi Kabupaten Konawe Selatan sebesar $17,92 \%$. Kontribusi yang diberikan usahatani lain memiliki nilai persentase sebesar $9,28 \%$, lebih kecil dibanding usahatani padi gogo. Kontribusi pendapatan non pertanian terhadap pendapatan rumahtangga memegang nilai terbesar dengan persentase $72,80 \%$. Petani di Desa Lelekaa Kecamatan Wolasi Kabupaten Konawe Selatan perlu menggunakan pupuk untuk meningkatkan produktivitas padi gogo dan sebaiknya proses produksi padi gogo lebih diutamakan pada tujuan komersil agar usahatani tersebut dapat memberikan kontribusi yang besar dan dapat menambah total pendapatan rumahtangga.

\section{REFERENSI}

Anton, M., \& Marhawati, G. (2016). Kontribusi Usahatani Padi Sawah Terhadap Pendapatan Usahatani Keluarga Di Desa Ogoamas li Kecamatan Sojol Utara Kabupaten Donggala. Agrotekbis, 4(1).

Arikunto, S. (2006). Metode Penelitian Kualitatif. Jakarta: Bumi Aksara.

Bhastoni, K., \& Yuliati, Y. (2016). Peran wanita tani di atas usia produktif dalam usahatani sayuran organik terhadap pendapatan rumah tangga di desa sumberejo kecamatan batu. Habitat, 26(2), 119-129.

BPS. (2018). Kecamatan Wolasi Dalam Angka Tahun 2018. Andoolo: Statistik Kabupaten Konawe Selatan.

Erna, E., Taridala, S. A. A., \& Indarsyih, Y. (2018). Analisis Komparatif Pendapatan dan Efisiensi Usahatani Padi Sawah Dengan Usahatani Padi Gogo di Kabupaten Konawe Selatan. JIA (Jurnal IImiah Agribisnis): Jurnal Agribisnis dan IImu Sosial Ekonomi Pertanian, 3(6), 135-140.

Fifin. (2018). Analisis Pendapatan dan Kontribusi Pendapatan Petani Pisang Raja terhadap Pendapatan Rumah Tangga di Desa Labulawa Kecamatan Pasir Putih Kabupaten Muna. In Skripsi (Ed.), Jurnal Sumberdaya Lahan Vol. Kendari: Fakultas Pertanian. UHO. 
Fitria, E., \& Ali, M. N. (2014). Kelayakan usaha tani padi gogo dengan pola Pengelolaan Tanaman Terpadu (PTT) di Kabupaten Aceh Besar, Provinsi Aceh. Widyariset, 17(3), 425-434.

Hariati, H., Limi, M. A., \& Fyka, S. A. (2018). Analisis Pendapatan dan Kontribusi Usahatani Padi Gogo (Oryza Sativa I.) Terhadap Pendapatan Rumahtangga di Desa Bubu Kecamatan Kambowa Kabupaten Buton Utara. JIA (Jurnal IImiah Agribisnis): Jurnal Agribisnis dan IImu Sosial Ekonomi Pertanian, 3(5), 130-134.

Hartono, T., Rosni, M., \& Salawati, U. (2020). Analisis Pendapatan Petani Padi Gogo (Oryza sativa L.) di Lahan Perbukitan Desa Pembakulan Kecamatan Batang Alai Timur Kabupaten Hulu Sungai Tengah. Frontier Agribisnis, 3(4).

Hernanto, F. (1989). IImu Usahatani. Jakarta: Penebar Swadaya.

Idjudin, A. A., \& Marwanto, S. (2008). Reformasi pengelolaan lahan kering untuk mendukung swasembada pangan. Jurnal Sumberdaya Lahan Vol, 2(2).

Iriyanto, E., Widayati, W., \& Taridala, S. A. A. (2019). Praktik Budidaya Padi Ladang Masyarakat Suku Tolaki di Desa Mata Wolasi Kecamatan Wolasi Kabupaten. Jurnal Ilmiah Membangun Desa dan Pertanian, 4(1), 281389.

Maluhima, S., Memah, M. Y., \& Sendow, M. M. (2020). Kontribusi Usahatani Padi Sawah Terhadap Pendapatan Keluarga Petani Di Desa Amongena li Kecamatan Langowan Timur Kabupaten Minahasa (Contribution of Rice Farming to Farmer's Family Income in Amongena II Village, East Lan-gowan District, Minahasa Regency). Journal of Agribusiness and Rural Development (Jurnal Agribisnis dan Pengembangan Pedesaan), 1(4).

Manginsela, E. P., \& Wangke, W. M. (2019). Kontribusi Usahatani Padi Sawah Terhadap Pendapatan Keluarga Di Kelurahan Taratara Satu Kecamatan Tomohon Barat Kota Tomohon. AgriSosioekonomi, 15(2), 235-242.

Mathieu, J. E., \& Zajac, D. M. (1990). A review and meta-analysis of the antecedents, correlates, and consequences of organizational commitment. Psychological bulletin, 108(2), 171.

Mulyadi, S. (2014). Ekonomi Sumber Daya Manusia dalam Perspektif Pembangunan. Jakarta: Rajawali Press.

Nurmala, N., \& Asse, M. (2020). Analisis Kontribusi Pendapatan Usahatani Cengkeh Terhadap Pendapatan Rumah Tangga Tani Di Desa Dungingis Kecamatan Dako Pemean Kabupaten Tolitoli (Studi Kasus Pada Kelompok Tani Mekar 2). Jurnal Agrotech, 10(1), 9-14.

Rahayu, M., Taufik, M., Tupaila, M., \& Hasid, R. (2019). Pendampingan teknik Budidaya Padi Gogo bagi Petani Wolasi (Good Agriculture Practise for Upland Rice Farmer. JURNAL KARYA PENGABDIAN, 1(3), 141-148.

Soekartawi. ( 2002). Prinsip Dasar Ekonomi Pertanian: Teori dan Aplikasinya. Jakarta: PT. Raja Grafindo Persada.

Soekartawi. ( 2016). Analisis Usahatani. Jakarta: UI-Press.

Suratiyah, K. (2015). IImu Usahatani. Jakarta: Penebar Swadaya.

Syamsiyah, N., Thoriq, A., Pardian, P., Karyani, T., \& Kusno, K. (2017). Tingkat Pendapatan Usahatani Padi Dan Kontribusinya Terhadap Pendapatan Petani. Jurnal Agribisnis Terpadu, 10(1), 76-88.

Taridala, S., Abdullah, W., Wahyuni, S., Wianti, N., Zani, M., Jabuddin, L., . . Ekaputri, A. (2018). Understanding the social and economic aspects of upland rice farming. Paper presented at the IOP Conference Series: Earth and Environmental Science.

Taridala, S. A. A., Abdullah, W. G., \& Wianti, N. I. (2016). Pemetaan Sosial Ekonomi Rumahtangga Petani Padi Gogo sebagai Dasar Kebijakan Menuju Kedaulatan Pangan di Kabupaten Konawe Selatan. Tidak dipublikasi.

Tuwo, M. A. (2011). IImu Usahatani: Teori dan Aplikasi Menuju Sukses. . Kendari: Unhalu Press.

Wahyunto, W., \& Widiastuti, F. (2017). Lahan sawah sebagai pendukung ketahanan pangan serta strategi pencapaian kemandirian pangan. 